\title{
Assessment of arsenic speciation and bioaccessibility in mine-impacted materials
}

Cameron J. Ollson $^{\mathrm{a}^{*}}$, Euan Smith ${ }^{\mathrm{a}}$, Kirk G. Scheckel ${ }^{\mathrm{b}}$, Aaron R. Betts ${ }^{\mathrm{b}}$ and Albert L. Juhasz ${ }^{\mathrm{a}}$

${ }^{a}$ Future Industries Institute, University of South Australia, Mawson Lakes, SA 5095, Australia.

${ }^{\mathrm{b}}$ United States Environmental Protection Agency, National Risk Management Research Laboratory, Land Remediation and Pollution Control Division, Cincinnati, OH, USA, 45224-1701

*Corresponding Author

Tel: $\quad+61424651276$

Email: cameron.ollson@mymail.unisa.edu.au

Address: Future Industries Institute, University of South Australia, Building X, Mawson Lakes, SA 5095, Australia.

\section{Keywords}

bioaccessibility, arsenic, tailings, calcinate, slime

\section{Highlights}

- Different mine materials have statistically dissimilar As bioaccessibility values

- As bioaccessibility is dependent on As and Fe speciation and particle size

- As:Amorphous Fe molar ratio describes As bioaccessibility in calcinated materials

- Default RBA values may not be appropriate for different mine-impacted materials

Manuscript word count: 4625 


\begin{abstract}
Mine-impacted materials were collected from Victoria, Australia and categorized into three source materials; tailings $(n=35)$, calcinated $(n=10)$ and grey slimes $(n=5)$. Arsenic (As) concentrations in these materials varied over several orders of magnitude $\left(30-47,000 \mathrm{mg} \mathrm{kg}^{-}\right.$ ${ }^{1}$ ), with median concentrations of 500, 10,800 and 1,500 $\mathrm{mg} \mathrm{kg}^{-1}$, respectively. When As bioaccessibility was assessed using the Solubility Bioaccessibility Research Consortium (SBRC) assay, As bioaccessibility ranged between 4 and 90\%, with mean gastric phase values of $30 \%, 49 \%$ and $82 \%$ for tailings, calcinated and grey slimes, respectively. An analysis of variance (ANOVA) determined that As bioaccessibility was significantly different $(\mathrm{P}<0.05)$ between source materials. This was due to differences in As mineralogy, soil particle size as well as the concentration and nature of Fe present. X-ray Absorption Near Edge Structure (XANES) analysis identified arseniosiderite, yukonite, realgar, loellingite and mineral sorbed arsenate species in mine-impacted materials. Despite differences in physicochemical properties, 'mine wastes' are often reported under a generic descriptor. Outcomes from this research highlight that variability in As bioaccessibility can be prescribed to As mineralogy and matrix physicochemical properties, while categorizing samples into sub-groups can provide some notional indication of potential exposure.
\end{abstract}




\section{Introduction}

Historic gold $\mathrm{(Au})$ mine sites exist throughout the world as a result of legacy activities. These sites are numerous and are typically associated with elevated concentrations of arsenic (As) due to the association of both As and $\mathrm{Au}$ with sulphidic phases in primary ores. Arsenic contamination at former mine sites is a consequence of Au extraction processes which result in three predominant matrices; tailings, calcinated and grey slime materials. Tailings are typically associated with the refuse material from crushing processes that separate valued minerals from ore. Calcinated materials are waste products resulting from high temperature treatment applied to Au-bearing ores that facilitates thermal decomposition, phase transition, removal of volatile fractions and Au recovery. In contrast, grey slimes are silty material that result from the beneficiation process of separating minerals from ore. Slimes are fine material predominantly collected from the bottom of settling tanks that are used to separate minerals from ore after the crushing process.

As a consequence of physical and thermal processes for the extraction of $\mathrm{Au}$, As mineralogy, concentration and other physicochemical properties of the contaminated matrix may vary which may impact on human health exposure assessment. Previous research has evaluated As bioaccessibility from these three mine-impacted materials; however, despite their different properties, it is often reported under a generic descriptor, i.e. mine waste [1-7]. Utilisation of a generic descriptor may lead to the misrepresentation of As bioaccessibility in individual mine-impacted materials, and therefore impact on human health exposure assessment. This generic descriptor has also lead to the adoption of single default relative bioavailability (RBA) values for As by regulators which may not be sufficiently protective of communities within As contaminated areas. For example, a region-specific As RBA value of $33 \%$ has been adopted for historic tailings in the gold mining region of Victoria, Australia (Meaklim 
personal communications). Other jurisdictions worldwide have adopted default As RBA values, such as the United States Environmental Protection Agency (US EPA; 60\% for As contaminated soils) [8], although site-specific evaluation is recommended. The default value was generated based on As bioaccessibility data from a limited number of samples, despite the fact that other mining waste materials are present at sites that have different physiochemical properties compared to tailings materials, e.g. calcinated materials and grey slimes.

The purpose of this research was to (1) evaluate the bioaccessibility of As from multiple mine waste sources (tailing, calcinated and slime materials) using the Solubility/Bioaccessibility Research Consortium (SBRC) assay, (2) use X-ray Absorption Near Edge Structure (XANES) analysis to evaluate if mineralogy is responsible for differences in As bioaccessibility, (3) evaluate the differences in As bioaccessibility between the three materials by assessing the relationship between As bioaccessibility and both total and reactive iron (citrate dithionite extractable $\mathrm{Fe}$ ), (4) determine if particle size can account for differences in As bioaccessibility, (5) assess the appropriateness of default values for As RBA by evaluating exposure for all mine-impacted materials.

\section{Materials and Methods}

\subsection{Mine impacted materials}

Materials used in this study were collected from areas contaminated with As through activities associated with $\mathrm{Au}$ extraction and recovery. Surface materials $(0-20 \mathrm{~cm})$ were collected from locations impacted by tailings $(n=35)$, calcinated materials $(n=10)$ and grey slimes $(n=5)($ Table 1). Following collection, materials were air dried then sieved to recover the $<2 \mathrm{~mm}$ and $<250 \mu \mathrm{m}$ particle size fractions. The $<250 \mu \mathrm{m}$ particle size fraction was 
utilised for As bioaccessibility assessment as it is the upper sized particle fraction that is believed to adhere to the hands of children and is available for hand-to-mouth transfer [9]. Total metal / metalloid concentrations in the $<2 \mathrm{~mm}$ and $<250 \mu \mathrm{m}$ particle size fraction was determined using Inductively Coupled Plasma - Optical Emission Spectroscopy (ICP-OES) following acid digestion using USEPA method 3051[10] in a Mars6 microwave (CEM).

In order to determine the concentration of reactive $\mathrm{Fe}$ (amorphous $\mathrm{Fe}$ and finely divided hematite and goethite) in the materials, citrate dithionite extractable Fe was undertaken using the method of Holmgren [11] with analysis by ICP-OES. Particle size analysis was performed on representative tailings, calcinated and slime materials using an Accusizer 780 Optical Particle Sizer. Particle size distribution was determined using Single Particle Optical Sensing (SPOS) or light obscuration to size particles. A $1 \mathrm{ml}$ aliquot of sample material $(0.1 \% \mathrm{w} / \mathrm{v}$ in Milli-Q water) was injected into the particle size chamber (containing $50 \mathrm{ml}$ Milli-Q water) at a flow rate of $50 \mathrm{ml} \mathrm{min}^{-1}$. Samples were analysed for 60 seconds with the results expressed as percentage contribution for four particle size ranges; $1 \mu \mathrm{m}$ to $25 \mu \mathrm{m},>25$ $\mu \mathrm{m}$ to $<50 \mu \mathrm{m},>50 \mu \mathrm{m}$ to $<200 \mu \mathrm{m}$, and $>200 \mu \mathrm{m}$ to $<250 \mu \mathrm{m}$.

\subsection{X-Ray absorption near edge structure (XANES) spectroscopy analysis}

To represent each matrix, two samples of each material were analysed. The samples that were selected were representative of the range in concentrations within the three materials. Samples were ground with a mortar and pestle, pressed into a pellet and mounted on Kapton tape prior to XANES analysis at Sector 10-BM, Advanced Photon Source, Argonne, USA [12]. The storage ring operated at $7 \mathrm{GeV}$ in top-up mode. A liquid $\mathrm{N}_{2}$ cooled double crystal Si(111) monochromator was used to select the incident photo energies and a platinum-coated mirror was used for harmonic rejection. Calibration was performed by assigning the first derivative inflection point of the K-edge of sodium arsenate (11874 eV) [13] with 
simultaneous collection of the reference for each scan for calibration of sample spectra. Arsenic X-ray absorption spectroscopy (XAS) spectra were collected in triplicate at the As K-edge $(11867 \mathrm{eV})$ in transmission and fluorescence using a 4-element Vortex florescence detector. Aluminum foil was used to cover the fluorescence detector window to suppress florescence from other elements (e.g. Fe) in the samples. Data analysis was conducted using Athena software [14]. Triplicate scans for each sample were merged, then normalized, and converted into $k$ space. Linear combination fitting (LCF) was used to identify As speciation in the samples $[13,15]$. Linear combination fits $(-30$ to $+70 \mathrm{eV}$ relative to the calibration energy) were performed using XAS normalized and derivative $\mu(E)$ spectra from reference standards to identify As phases in the soil samples. During the LCF, components were only allowed to contribute to the model if the sum-square error was reduced by $20 \%$ [16]. The Rfactor is a measure of the mean square sum of misfit at each data point and describes the degree of uncertainty in the fitting process [17].

Reference materials for As LCF included dimethyl arsenate, monomethyl arsenate, beudantite $\left(\mathrm{PbFe}_{3}\left(\mathrm{AsO}_{4}\right) \mathrm{SO}_{4}(\mathrm{OH})_{6}\right), \quad$ arseniosiderite $\quad\left(\mathrm{Ca}_{2} \mathrm{Fe}^{3+}{ }_{3}\left(\mathrm{AsO}_{4}\right)_{3} \mathrm{O}_{2} \cdot 3\left(\mathrm{H}_{2} \mathrm{O}\right)\right), \quad$ scorodite $\left(\mathrm{FeAsO}_{4} \cdot 2\left(\mathrm{H}_{2} \mathrm{O}\right)\right)$, orpiment $\left(\mathrm{As}_{2} \mathrm{~S}_{3}\right)$, realgar $\left(\mathrm{As}_{4} \mathrm{~S}_{4}\right)$, arsenate sorbed to gibbsite $\left(\mathrm{Al}(\mathrm{OH})_{3}\right)$, arsenate sorbed to hematite $\left(\mathrm{Fe}_{2} \mathrm{O}_{3}\right)$, arsenate sorbed to goethite $(\alpha-\mathrm{FeOOH})$, arsenate sorbed to ferrihydrite, arsenate sorbed to birnessite $\left(\mathrm{MnO}_{2}\right)$, arsenite adsorbed to ferrihydrite, arsenite adsorbed to pyrite $\left(\mathrm{FeS}_{2}\right)$, arsenite sorbed to fougerite $\left(\mathrm{Fe}^{2+}{ }_{3} \mathrm{Fe}^{3+}\left[(\mathrm{OH})_{8}\right]^{+}\left[\mathrm{Cl}, \mathrm{H}_{2} \mathrm{O}\right]^{-}\right)$, arsenite sorbed to mackinawite $\left((\mathrm{Fe}, \mathrm{Ni}) \mathrm{S}_{0.9}\right)$, arsenite sorbed to siderite $\left(\mathrm{FeCO}_{3}\right)$, lollingite $\left(\mathrm{FeAs}_{2}\right)$, arsenolite $\left(\mathrm{As}_{4} \mathrm{O}_{6}\right)$, yukonite $\left(\mathrm{Ca}_{7} \mathrm{Fe}^{3+}{ }_{11}\left(\mathrm{AsO}_{4}\right)_{9} \mathrm{O}_{10} \cdot 24.3\left(\mathrm{H}_{2} \mathrm{O}\right)\right)$, arsenopyrite (FeAsS), and schneiderhohnite $\left(\mathrm{Fe}^{2+} \mathrm{Fe}^{3+}{ }_{3} \mathrm{As}_{5} \mathrm{O}_{13}\right)$. Data for LCF fits reveal As speciation in each soil as ratios of these mineral forms. 


\subsection{Assessment of As bioaccessibility}

Arsenic bioaccessibility in mine-impacted materials was determined using the $<250 \mu \mathrm{m}$ particle size fraction and the gastric phase of the SBRC assay. This method is recommended by the US EPA based on strong statistical comparison to As relative bioavailability (RBA) determined using in vivo models [18-20]. Mine-impacted materials $(n=50 ; 3$ replicates of each sample) were combined with gastric phase solution $\left(30.03 \mathrm{~g}^{-1}\right.$ glycine adjusted to $\mathrm{pH}$ 1.5 with concentrated $\mathrm{HCl}$ ) to achieve a soil:solution ratio of 1:100. Samples were incubated at $37^{\circ} \mathrm{C}, 40 \mathrm{rpm}$ on a Ratek suspension mixer for $1 \mathrm{~h}$ ensuring that the $\mathrm{pH}$ was maintained at 1.5. After gastric phase extraction, samples $(10 \mathrm{ml})$ were collected and filtered through 0.45 $\mu \mathrm{m}$ filters for analysis by ICP-MS or OES. Arsenic bioaccessibility was calculated by dividing the gastric phase extractable As by the total soil As concentration (Equation 1).

$$
\text { As bioaccessibility }(\%)=\left[\frac{\text { In vitro As }}{\text { Total As }}\right] * 100 \quad \text { Equation } 1
$$

Where:

In vitro As $=A s(\mu \mathrm{g})$ extracted from soil following gastric $($ SBRC-G) phase treatment.

Total As $=$ As $(\mu \mathrm{g})$ present in contaminated soil added to the in vitro assay prior to treatment $[21]$

A one way analysis of variance (ANOVA; SPSS version 21) was used to determine statistical differences in As bioaccessibility between the mine-impacted materials.

\subsection{Evaluation of risk to human health}

The potential risk to human health resulting from oral exposure to As in the studied materials was evaluated using the human health risk assessment approach detailed in Schedule B4 of 
the National Environmental Protection (Assessment of Site Contamination) Measure (NEPMASC) guidelines [22]. Using this approach, the level of risk to human health is only acceptable when the hazard quotient (HQ) is $<1$. The HQ was determined using the following equation:

$$
\mathrm{HQ}=\quad \frac{\text { Estimated Daily Intake }(\mathrm{EDI})}{\text { Tolerable Daily Intake }(\mathrm{TDI})}
$$

Equation 2

Where:

Tolerable Daily Intake (TDI) $=$ the maximum concentration of a substance that if consumed over a lifetime will not result in appreciable health risk [23]. For As, the TDI is $0.002 \mathrm{mg}$ As/kg/day for both children and adults as prescribed by the NEPM-ASC [22].

Estimated daily intake $(E D I)=$ quantifiable estimate of the level a receptor is exposed on a daily basis ( $\mathrm{mg} / \mathrm{kg} / \mathrm{bw} / \mathrm{day})$ and was calculated as follows:

$$
\mathrm{EDI}=\frac{\operatorname{COC} \text { Concentration * Exposure Factors * Relative Absorption Factor (RAF) }}{\text { Body Weight }} \text { Equation } 3
$$

Where:

$\mathrm{COC}$ concentration $=$ the concentration $\left(\right.$ e.g. $\mathrm{mg} \mathrm{kg}^{-1}$ ) of the contaminant (i.e. As) in the soil matrix.

Exposure factors $=$ the rate of exposure for a receptor to the contaminated soil (e.g., days/year). The exposure scenario is for a child with an exposure duration and frequency of 6 years and 365 days respectively.

Relative absorption factor $=$ refers to the portion of a chemical that will enter the systemic circulation via the exposure route of interest (i.e. bioavailable fraction). In Australia, it is assumed that for oral exposure routes, the RAF is $100 \%$ [22], however, this value may be modified through the provision of site-specific data (i.e. bioaccessibility assessment). 
Body weight $=$ weight of a child, $15 \mathrm{~kg}$.

In addition, EDI and HQ were also calculated using the default As RBA for historic tailings materials in Victoria, Australia (33\%; Meaklim personal communications).

Arsenic RBA in mine-impacted materials was predicted using data obtained from bioaccessibility assessment and in vivo-in vitro linear regression model from Juhasz et al. [20] (Equation 4). RBA is a value that accounts for the amount of a contaminant that reaches systemic circulation following exposure to contaminated soil. This measurement is further refined by comparing it to a contaminant-specific reference dose [24] .

$$
\text { As RBA }=1.66+(0.992) S B R C \text {-gastric }(\%) R^{2}=0.754
$$

Equation 4

\subsection{Quality assurance and quality control}

During the analysis of As concentration in the materials, a certified reference material (GBW 07411) was included in the digest and analytical procedures for quality assurance and quality control. The accuracy of the aqua-regia digestion method was confirmed by a quantitative average As recovery of 2,660 $\pm 60 \mathrm{mg} \mathrm{kg}^{-1}(\mathrm{n}=3)$ from $\mathrm{GBW} 07411\left(2,700 \mathrm{mg} \mathrm{As} \mathrm{kg}^{-1}\right)$. During the determination of metal/metalloid concentrations in material digests and in vitro extracts, duplicate analysis, spiked sample recoveries and check values were included. The average deviation between duplicate samples $(n=4)$ was $1.8 \%$, the average recovery from spiked samples $(n=4)$ was $102 \%$ whereas check value recoveries $(n=12)$ ranged from 97.0$103 \%$ (99\% average recovery) for As and 94.8-103\% (100\% average recovery) for Fe. During particle size analysis, the difference in particle size distribution between replicate samples was $<7 \%$. 


\section{Results and Discussion}

\subsection{Material properties}

Initially, mine-impacted materials were separated into three categories (tailings, calcinated materials and grey slimes) based on visual observations. Calcinated materials were characteristically purple in colour while slimes were grey. Tailings were the most heterogeneous grouping and represented materials that were not identified as either calcinated or slimes. Table 1 details the concentration of major and minor elements in the $<2 \mathrm{~mm}$ particle size fraction for the three mine-impacted matrix classifications. The concentration of As varied over several orders of magnitude with concentrations ranging from 30-3,160 (mean $=711 ; \mathrm{n}=35), 736-47,100($ mean $=14,100 ; \mathrm{n}=10)$ and $1,370-2,310 \mathrm{mg} \mathrm{kg}^{-1}($ mean = 1,760; $\mathrm{n}=5$ ) for tailings, calcinated materials and grey slimes, respectively. Characteristically, calcinated materials contained elevated concentrations of copper $(\mathrm{Cu}), \mathrm{Fe}$, manganese $(\mathrm{Mn})$, phosphorus $(\mathrm{P})$, lead $(\mathrm{Pb})$ and zinc $(\mathrm{Zn})$ compared to tailing and grey slimes. Of the 50 mineimpacted materials analysed, 46 exceeded the NEPM-ASC As health investigation level (HIL) for residential scenario A (100 $\left.\mathrm{mg} \mathrm{kg}^{-1}\right)$ [22]. In addition, the NEPM-ASC health investigation level for $\mathrm{Pb}$ and $\mathrm{Cu}$ was exceeded in 13 (5 tailings and 8 calcinated samples) and 2 samples (calcinated samples), respectively. When the concentration of As in the $<2$ $\mathrm{mm}$ and $<250 \mu \mathrm{m}$ particle size fractions were compared, some variability was observed for individual samples (Figure 1) although enrichment in the smaller particle size fraction was not observed.

\subsection{Assessment of As Bioaccessibility}

Arsenic bioaccessibility in tailings, calcinated materials and grey slimes was assessed using the gastric phase of the SBRC assay. This in vitro methodology was utilised as a number of researchers have demonstrated a strong relationship between As bioaccessibility and As 
relative bioavailability $[18-20,25]$. As a result, the SBRC gastric phase has been recommended by some regulatory agencies as a surrogate measure of As RBA for the refinement of exposure in human health risk assessment [22]. As detailed in Figure 2, As bioaccessibility in mine-impacted materials varied markedly. For materials classified as tailings, As bioaccessibility ranged from $4-70 \%($ mean $=30 \%)$ while for calcinated materials, As bioaccessibility ranged from $25-84 \%($ mean $=48 \%)$. In contrast, As bioaccessibility was less variable in grey slimes with values ranging from 70-90\% $($ mean $=82 \%)$. Although there was considerable variability in As bioaccessibility observed in mine-impacted materials, an ANOVA determined there was significant difference $(\mathrm{P}<0.05)$ in As bioaccessibility between the tailings, calcinated material and grey slimes.

Previous studies evaluating mine site materials have reported As bioaccessibility to be variable. Despite describing the materials as 'mine waste', this research was likely carried out on tailings materials due to their prevalence compared to calcinated and slime matrices. For example, using the SBRC gastric phase, Bradham et al. [18] reported an As bioaccessibility range from 1 to $74 \%(\mathrm{n}=27)$, while Brattin et al. [25] reported a range from 6 to $78 \%(\mathrm{n}=15)$.

Previous research has highlighted the importance of As mineralogy and soil physicochemical properties on the dissolution of As from contaminated soils [6, 19, 24, 26]. For example, Meunier et al. [6] reported that the difference in As bioaccessibility in mines waste from six abandoned gold mines in Nova Scotia, Canada, was a consequence of differences is As mineralogy and their propensity for dissolution under low $\mathrm{pH}$ gastric conditions. In order to determine if As mineralogy was a key parameter that influenced As bioaccessibility in tailings, calcinated material and grey slimes, XANES analysis was undertaken on selected mine-impacted materials. 


\subsection{Impact of As mineralogy on As bioaccessibility}

As detailed in Table 2, XANES analysis of the $<250 \mu \mathrm{m}$ particle size fraction of tailings, calcinated and slime materials indicated that As was present as realgar, arseniosiderite, yukonite, loellingite or as mineral sorbed arsenate species. Tailings samples contained realgar $(13 \%)$ and/or loellingite $(11 \%)$ phases while only a small fraction $(<10 \%)$ of realgar was found in calcinated sample \#4568. Similarly, loellingite comprised a small fraction $(<10 \%)$ of slime sample BH1-100 (Table 2). Arsenic was also present in tailings, calcinated and slime materials as arseniosiderite, yukonite and mineral sorbed arsenate, however, the contribution of these phases varied between and within classification categories (Table 2). Arseniosiderite and mineral sorbed arsenate species were present in all samples, with the exception of \#4568 (calcinated material) and BH12 (tailings) respectively with weighted percentages ranging from $24-69 \%$ (arseniosiderite) and $10-74 \%$ (sorbed arsenate). In contrast, yukonite was present in all samples with weighted percentages ranging from $<10-37 \%$.

Although arsenopyrite was not identified in either tailings, calcinated or slime materials, weathering processes may have resulted in its oxidation leading to the formation of arseniosiderite [27]. The presence of these minerals in tailing materials have been reported by other researchers. Kim et al. [28] identified arseniosiderite phases in mine wastes from California while Meunier et al. [6] found arseniosiderite and yukonite in tailings samples from a gold mine site in Canada. In addition, weathering of As-bearing phases may result in the sorption of dissolved arsenic to Fe hydroxides $[28,29]$ as observed in these samples.

A number of researchers $[6,26,30]$ have determined that As dissolution at low $\mathrm{pH}$ (i.e. gastric phase conditions) is dependent on mineralogy. As detailed by Ruby et al. [26], the 
bioaccessibility of As bearing phases, As sulphides, FeAs oxides and As trioxide, increases under gastric phase conditions. In a comprehensive study, Meunier et al. [6] determined that As mineral phases that contributed to As bioaccessibility (in increasing order) included As sulphides (e.g. realgar), iron arsenates (e.g. loellingite), As-bearing Fe(oxy)hydroxides, roaster iron oxides, sulphates, clay minerals and calcium-Fe arsenates (e.g. yukonite). Although, arseniosiderite is classified as a calcium-Fe arsenate, its thermodynamic properties are not well understood at low $\mathrm{pH}$ conditions $[30,31]$. In addition, the solubility of mineral sorbed arsenate under gastric phase conditions is dependent on the matrix to which it is adsorbed (i.e. mineralogy of $\mathrm{Fe}$ ) $[15,32]$. Although the concentration of reactive Fe in mineimpacted material was assessed (see below), mineralogical assessment using XANES analysis was not undertaken.

As detailed in Table 2, As mineralogy alone is not the only physicochemical parameter that may influence As bioaccessibility, as indicted by the significant difference in bioaccessibility values for tailings samples GA1 (19.0\%) and BH12 (64.7\%). Similar findings have been observed by other researchers [6, 30]. Arsenic bioaccessibility varied considerably for samples classified as tailings (Figure 2) which may be reflective of differences in base ore characteristics, ore processing methodologies (e.g. crushing method, time housed in tailings holding areas), environmental parameters that influence weathering and physicochemical properties of the matrix $[28,33,34]$. As physicochemical parameter, such as $\mathrm{Fe}$ concentration and speciation and particle size distribution have been shown to influence As bioaccessibility [6, 28, 35], additional analysis was undertaken to determine if these parameters can explain the variability in As bioaccessibility. 


\subsection{Impact of Fe on As bioaccessibility}

Previous studies have highlighted the importance of the association between As and both crystalline and amorphous forms of $\mathrm{Fe}[6,35]$ on As bioaccessibility. It has been reported that the most commonly associated As phase is one that is sorbed to $\mathrm{Fe}$ oxides or oxyhydroxides, specifically amorphous Fe [36, 37]. The retention of As sorbed to Fe oxides and oxyhydroxides is variable and dependent on $\mathrm{pH}$, As species and surface area [35]. Although XANES analysis was not undertaken for the determination of Fe mineralogy in these samples, reactive (ie. citrate dithionite extractable Fe comprising amorphous Fe and finely divided hematite and goethite) and total Fe was assessed and compared to As bioaccessibility. Figure 3 illustrates that there were considerable differences in both total and reactive $\mathrm{Fe}$ concentrations in tailings, calcinated and grey slime materials. Low concentrations of reactive $\mathrm{Fe}$ was present in calcinated and slime materials. This was expected in calcinated material as amorphous Fe would undergo crystallization during thermal treatment involved in the calcination process. A weak relationship existed between reactive and total $\mathrm{Fe}$ in tailing samples, although the strength of the relationship was influenced by variability resulting from differing parent materials and weathering / oxidation processes that affect chemical form. However, when the influence of reactive Fe on As bioaccessibility was determined, $82 \%$ of the variance in As bioaccessibility could be accounted for by the As:reactive Fe molar ratio for calcinated materials, (Figure 4). Although reactive $\mathrm{Fe}$ in calcinated material was low relative to total $\mathrm{Fe}$, arsenate absorption to more crystalline Fe phases (e.g. hematite, maghemite, magnetite; Walker et al.[29]) may occur via bidentate-binuclear complexes as a consequence of the high As coverage [32, 38]. While As(reactive)Fe interactions appear to influence As bioaccessibility in these materials, 'roasterderived' As-bearing matrices have little analogy to better studies naturally occurring As 
minerals [29] and as such mechanisms controlling As bioaccessibility warrants further investigation. It appeared that slime material followed a similar trend to calcinated samples, however, due to the limited sample size $(n=5)$, statistical evaluation was inconclusive $\left(\mathrm{R}^{2}=0.15\right)$. In contrast, the relationship between As:reactive $\mathrm{Fe}$ molar ratio and As bioaccessibility for tailing samples was unclear as a consequence of heterogeneity associated with the sample type.

\subsection{Impact of particle size on As bioaccessibility}

In addition to As speciation and As-Fe interactions, particle size distribution plays an important role in As bioaccessibility. Particle size will influence surface area to volume ratio which will impact the rate and extent of As bearing mineral dissolution under gastric phase conditions [26, 39]. As detailed in Table 3, particle size distribution was similar for each material classified within calcinated and grey slime categories, however, a significant difference $(\mathrm{P}<0.05)$ was observed between the two tailing samples. In GA1, 79\% of the sample was in the $>200 \mu \mathrm{m}$ to $<250 \mu \mathrm{m}$ particle size range, whereas the majority of $\mathrm{BH} 12$ (85\%) was in the $<25 \mu \mathrm{m}$ particle size range. Although XANES analysis identified similarities between GA1 and BH12 with respect to As speciation, the difference in As bioaccessibility (19.0\% and $64.7 \%$ respectively) may be attributable to the significant difference in particle size distribution. Greater dissolution of As under gastric phase conditions occurred in $\mathrm{BH} 12$ as a consequence of the greater surface area to volume ratio. Although studies assessing the influence of particle size on the dissolution of pure As mineral are lacking, increasing As bioaccessibility in contaminated soil with decreasing particle size has been observed by a number of researchers [33, 39-41]. For tailings materials, variability in particle size distribution may arise as a consequence of differences in ore processing in addition to environmental parameters that influence weathering. 
As detailed above (sections 3.3-3.5), predicting As bioaccessibility in mine-impacted materials is complicated as dissolution under gastric phases conditions is influenced by both mineralogical (As, Fe) and matrix (particle size) factors. These factors, in turn, may be influenced by ore processing methodologies and environmental parameters that impact the weathering of primary ores (i.e. secondary mineral formation) in addition to exerting an effect on morphological properties (e.g. encapsulation).

\subsection{Impact of As bioaccessibility on human health exposure assessment}

Total As concentration in mine-impacted materials was used as an input parameters into the human health risk assessment model as prescribed by NEPM-ASC (2013). A maximum EDI of $0.002 \mathrm{mg} \mathrm{As} \mathrm{kg}^{-1}$ day was used as the threshold level to compare exposure calculated using default bioavailability assumption (i.e. 100\%; NEPM-ASC or 33\%; tailings values for historical mine waste in Victoria) or site-specific As RBA derived from As bioaccessibility measurement and the in vivo-in vitro linear regression model [18].

Figure 5 shows EDI values for tailings (A-B), calcinated (C) and grey slime material (D) using default and predicted As RBA values. Of the 31 tailings samples assessed (i.e. those that exceeded the HILa soil screening level), 7 were below the threshold level when the soil ingestion pathway was assessed using a default As RBA value of 1. Conceivably, threshold levels may be exceeded when other exposure pathways are considered. However, significant variability was observed for the remaining 24 tailings samples when default or site-specific As RBA values were used to calculate EDI. Using the default RBA value of 1 resulted in exceedance of the threshold value for all 24 tailings samples with EDIs ranging from 0.0023 $0.021 \mathrm{mg} \mathrm{As} \mathrm{kg}^{-1}$ day. However, when the historic tailing As RBA default value was included 
in EDI calculations, the number of soils exceeding the threshold value was reduced to 11 . Similarly, when site-specific As RBA values were used to calculate EDI, 11 tailings exceeded the threshold value although there were differences between EDI values when 'default' and site-specific As RBA was utilised. For example, in samples SB6, SB8, SB11 and GA13, utilising the historic tailings default As RBA value (33\%) for EDI calculations resulted in a more conservative estimate of As intake (31-136\% higher than site-specific values). In contrast, default As RBA assumptions resulted in significantly lower EDI values (51-88\%) compared to site-specific calculations for SB3 and SB15.

Calcinated $(n=10)$ and slime samples $(n=5)$ exceeded EDI irrespective of RBA scenario, with the exception of TP41 where site-specific As RBA or the Victorian default RBA value reduced estimated exposure to below the maximum threshold level for the soil ingestion pathway (Figures 5c and 5d, respectively).

\section{Conclusion}

Although variability in As bioaccessibility was observed for mine impacted material, significant differences were observed between tailings, calcinated and grey slimes. This has implications for human health exposure assessment, particularly if default As RBA values are utilised. Default values (e.g. 33\% for historical tailing materials or 60\% for As in soil [8]) may not be protective of human health, depending on the nature of the material assessed. As a consequence, site-specific assessment of As bioaccessibility is recommended in order to improve risk characterization.

Furthermore, in order to accurately assess human health exposure at mine sites, it is pertinent that mine impacted material be categorised based on source material and associated processing procedures instead of the generic category 'mine waste'. 


\section{Acknowledgements}

The authors acknowledge the support of the Future Industries Institute, University of South Australia and the Cooperative Research Centre for Contamination Assessment and Remediation of the Environment (CRC CARE) (Project 3.1.07.11/12). XANES analysis was performed at the Advanced Photon Source (APS), Argonne, Illinois, USA. MRCAT operations are supported by the Department of Energy and the MRCAT member institutions. This research used resources of the APS, a U.S. Department of Energy (DOE) Office of Science User Facility operated for the DOE Office of Science by Argonne National Laboratory under Contract No. DE-AC02-06CH11357. Although EPA contributed to this article, the research presented was not performed by or funded by EPA and was not subject to EPA's quality system requirements. Consequently, the views, interpretations, and conclusions expressed in this article are solely those of the authors and do not necessarily reflect or represent EPA's views or policies. 


\section{List of Figures}

Figure 1. Comparison of arsenic concentration in the $<2 \mathrm{~mm}$ and $<250 \mu \mathrm{m}$ soil particle size fractions for tailings $(\boldsymbol{\square})$, calcinated materials $(\diamond)$ and grey slimes $(\square)$.

Figure 2. Box plot of As bioaccessibility for mine-impacted materials; tailings, calcinated materials and slimes. Each box represents the lower and upper quartiles, and the band within the box represents the median As bioaccessibility value. Whiskers represent minimum and maximum values for As bioaccessibility determined using the gastric phase of the SBRC assay.

Figure 3. Comparison of total and reactive $\mathrm{Fe}\left(\mathrm{g} \mathrm{kg}^{-1}\right)$ in tailings $(\boldsymbol{\square})$, calcinated materials $(\diamond)$ and grey slimes $(\square)$.

Figure 4. Relationship between bioaccessible As $\left(\mathrm{mg} \mathrm{kg}^{-1}\right)$ and the As:reactive Fe molar ratio in tailings $(\square)$, calcinated materials $(\diamond)($ A) and grey slimes $(\square)(B)$.

Figure 5. Estimated daily As intake from the incidental ingestion of mining samples calculated using the NEPM-ASC default As RBA value of 1 (ם), site-specific values determined using SBRC gastric phase extraction and the in vivo-in vitro linear regression model of Juhasz et al. (2014) ( $\square$ ) and the default region-specific value for historic tailing material ( $\mathbf{\square})$; Figures $\mathrm{A}$ and $\mathrm{B}$ represent tailing samples while figures $\mathrm{C}$ and $\mathrm{D}$ represent calcinated and slime samples respectively. The dotted line represents the maximum allowable EDI of $0.002 \mathrm{mg} / \mathrm{kg} / \mathrm{bw} / \mathrm{day}(\mathrm{NEPM}, 2013)$. 
Figure 1.

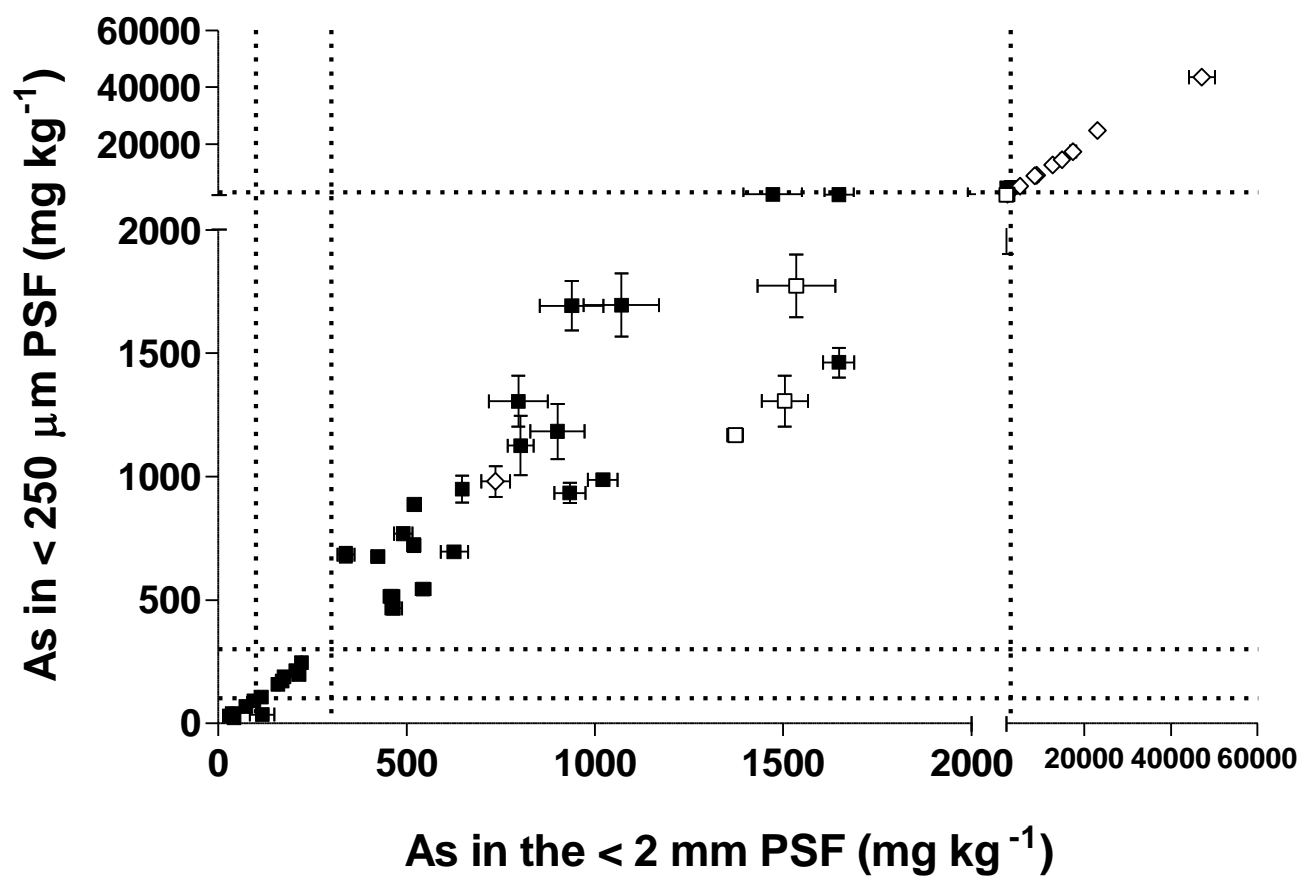


Figure 2.

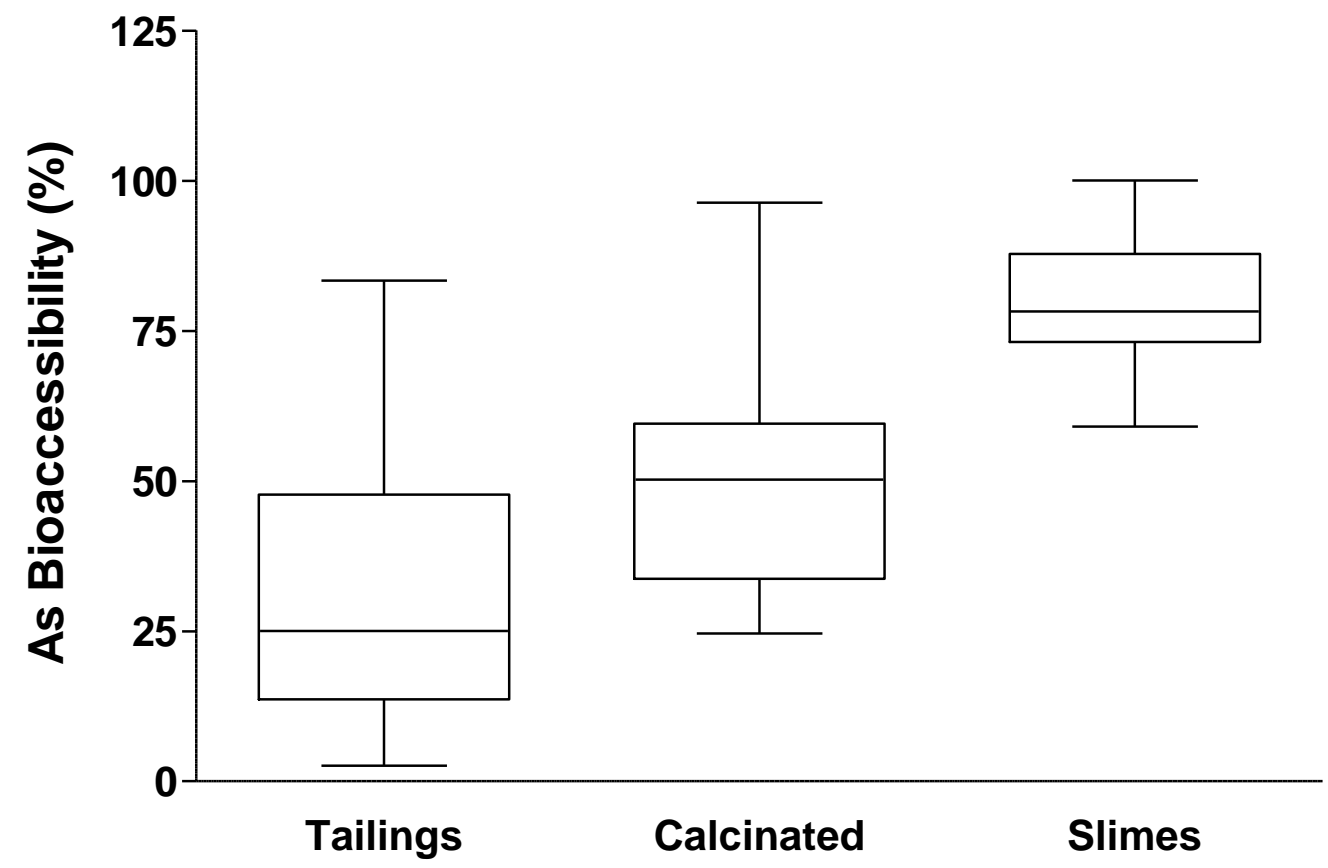


Figure 3.

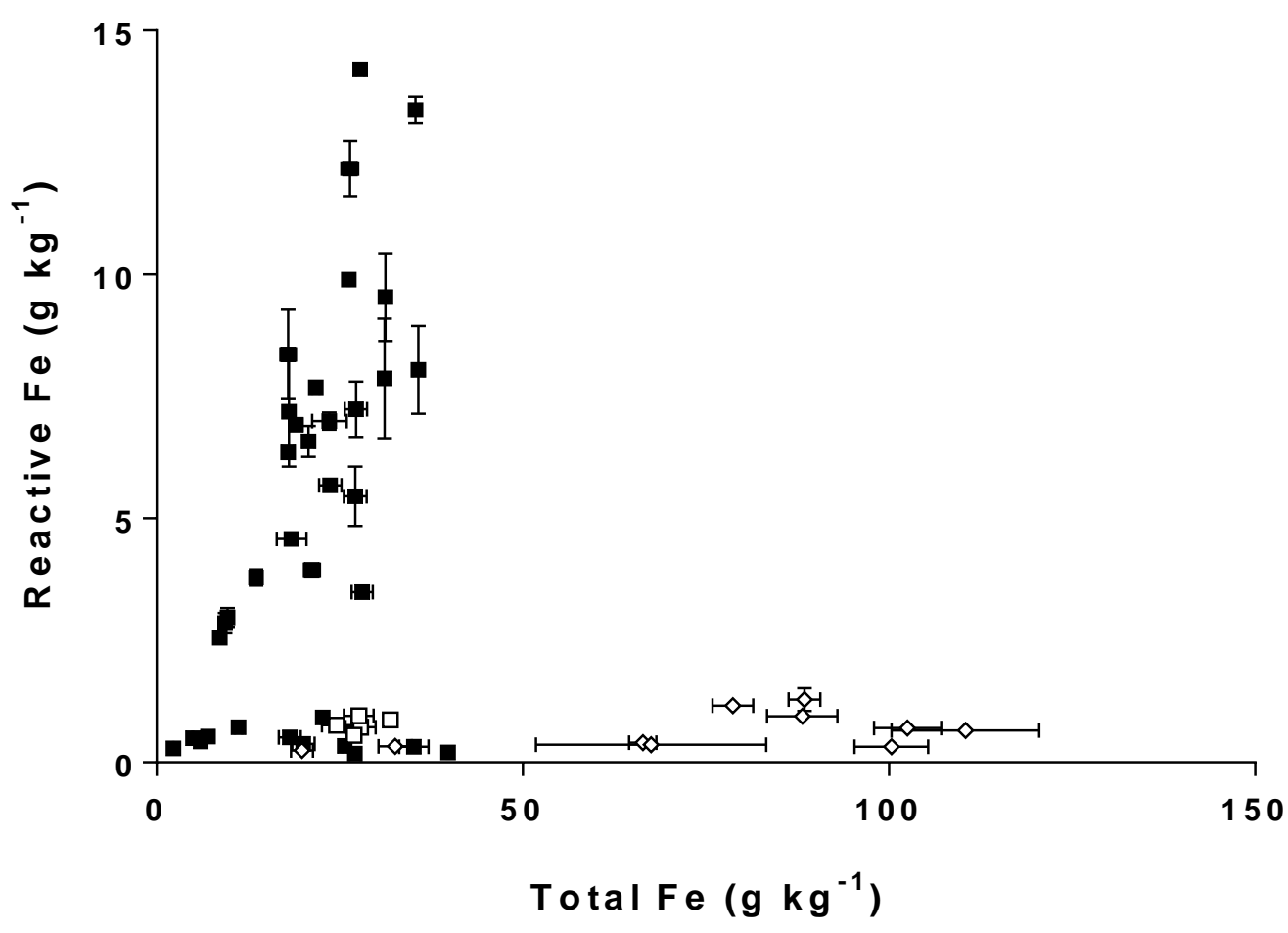


Figure 4.
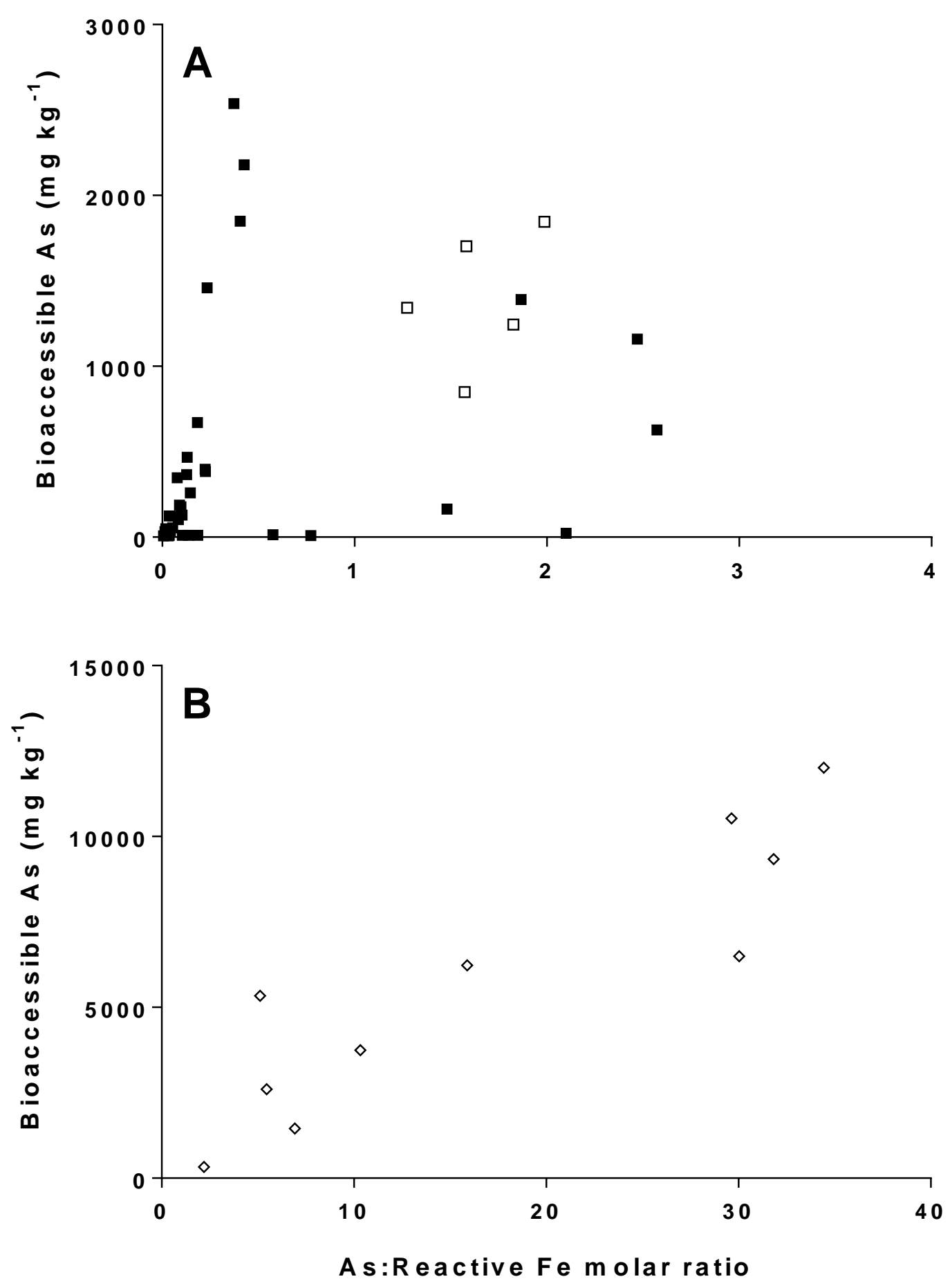
Figure 5.
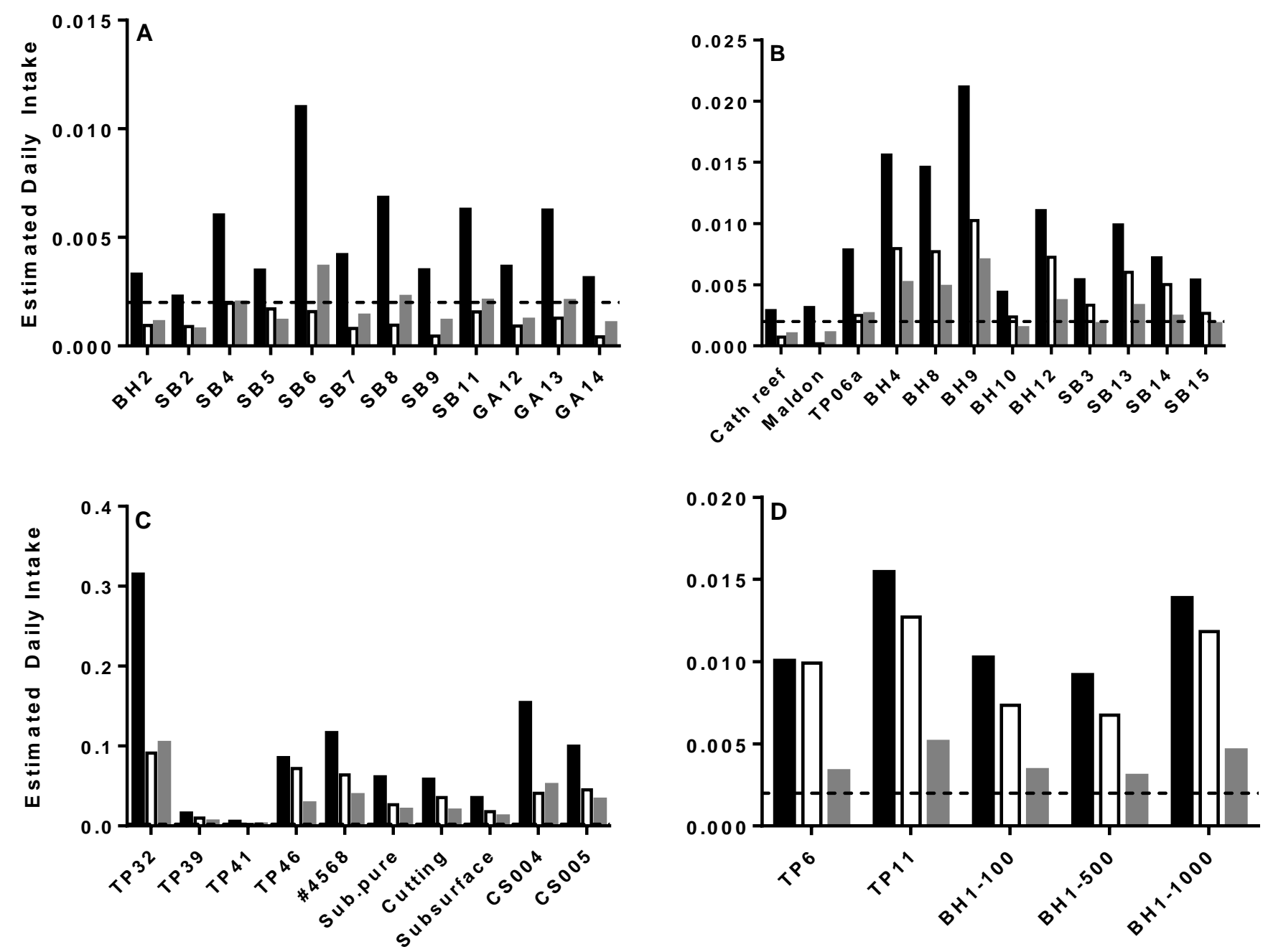
Table 1. Total Concentration of minor and major elements in mine-impacted materials.

\begin{tabular}{|c|c|c|c|c|c|c|c|c|c|c|c|}
\hline \multirow[b]{2}{*}{ Material } & \multirow[b]{2}{*}{$\begin{array}{c}\text { Metrics } \\
\text { Min. }\end{array}$} & \multicolumn{7}{|c|}{ Minor Elements (mg kg $\left.{ }^{-1}\right)$} & \multicolumn{3}{|c|}{ Major Elements $\left(\mathrm{g} \mathrm{kg}^{-1}\right)$} \\
\hline & & As & Cd & $\mathbf{C u}$ & Mn & $\mathbf{P}$ & $\mathbf{P b}$ & Zn & Al & $\begin{array}{c}\mathbf{F e} \\
2.20\end{array}$ & Mg \\
\hline \multirow{5}{*}{$\begin{array}{l}\text { Tailings } \\
(\mathrm{n}=35)\end{array}$} & & 29.8 & 0.10 & 2.60 & 6.20 & 34.4 & 5.60 & 5.10 & 0.20 & $(0.18) \dagger$ & 0.10 \\
\hline & Max. & 3,160 & 10.1 & 2,980 & 703 & 760 & 1,810 & 1,770 & 14.1 & $40.1(14)$ & 8.90 \\
\hline & Mean & 711 & 1.10 & 199 & 300 & 422 & 162 & 237 & 5.20 & $19.1(4.8)$ & 3.40 \\
\hline & Median & 505 & 0.40 & 30.4 & 337 & 465 & 35.4 & 153 & 4.90 & $19.2(4.3)$ & 3.10 \\
\hline & n exceeding HILa* & 31 & 0 & 0 & 0 & na & 5 & 0 & na & na & na \\
\hline \multirow{5}{*}{$\begin{array}{c}\text { Calcinated } \\
(\mathrm{n}=10)\end{array}$} & Min. & 736 & 0.10 & 30.0 & 229 & 218 & 72.3 & 81.0 & 4.80 & $19.3(0.25)$ & 1.70 \\
\hline & Max. & 47,100 & 12.8 & 24,600 & 3,740 & 5,950 & 1,170 & 1,846 & 19.4 & $112(1.3)$ & 45.0 \\
\hline & Mean & 14,100 & 3.70 & 4,150 & 889 & 1,280 & 681 & 905 & 8.70 & $72.7(0.64)$ & 13.0 \\
\hline & Median & 10,900 & 2.50 & 306 & 675 & 808 & 791 & 748 & 7.30 & $71.4(0.53)$ & 11.6 \\
\hline & n exceeding HILa & 10 & 0 & 2.0 & 0 & $\mathrm{Na}$ & 8 & 0 & $\mathrm{Na}$ & na & $\mathrm{Na}$ \\
\hline \multirow{5}{*}{$\begin{array}{l}\text { Slimes } \\
(n=5)\end{array}$} & Min. & 1,370 & 0.20 & 25.7 & 238 & 576 & 32.3 & 100 & 10.5 & $23.5(0.55)$ & 7.30 \\
\hline & Max. & 2,310 & 0.30 & 208 & 619 & 817 & 46.3 & 279 & 14.3 & $31.9(0.96)$ & 11.8 \\
\hline & Mean & 1,760 & 0.20 & 65.1 & 389 & 708 & 38.8 & 178 & 12.1 & $27.4(0.77)$ & 9.90 \\
\hline & Median & 1,540 & 0.20 & 29.0 & 355 & 717 & 37.8 & 122 & 12.0 & $28.0(0.76)$ & 10.3 \\
\hline & n exceeding HILa & 5 & 0 & 0 & 0 & na & 0 & 0 & na & na & na \\
\hline
\end{tabular}

*National Environment Protection Measure (NEPM) Health Investigation Level (HIL) a: Residential with garden accessible soil (home grown produce <10\% fruit and vegetable intake, (no poultry), also includes children's day care centres, preschools and primary schools (NEPM, 2013).

$\dagger$ Values in parenthesis represent citrate dithionite extractable Fe (reactive Fe) 
Table 2. Linear Combination Fitting (LCF)-XANES analysis of As speciation in selected mine-impacted materials.

Weighted Percentage

\begin{tabular}{|c|c|c|c|c|c|c|c|c|c|c|c|}
\hline Sample & Classification & pH & $\begin{array}{c}\text { As } \\
\left(\mathrm{mg} \mathrm{kg}^{-1}\right)\end{array}$ & $\begin{array}{c}\mathrm{Fe} \\
\left(\mathrm{g} \mathrm{kg}^{-1}\right)\end{array}$ & $\begin{array}{c}\text { As IVBA* } \\
(\%)\end{array}$ & Arseniosiderite & Yukonite & Realgar & Loellingite & $\begin{array}{c}\text { Adsorbed } \\
\qquad \mathbf{A s}^{\mathrm{v}}\end{array}$ & R-factor \\
\hline GA1 & Tailings & 6.0 & $170 \pm 4$ & $13.6 \pm 0.1$ & $19.0 \pm 1.1$ & 66 & 13 & & 11 & 10 & 0.035 \\
\hline BH12 & Tailings & 8.1 & $2270 \pm 108$ & $27.2 \pm 1.5$ & $64.7 \pm 2.9$ & 57 & 20 & 13 & 11 & & 0.089 \\
\hline \#4568 & Calcinated & 7.8 & $17400 \pm 694$ & $66.4 \pm 1.9$ & $53.9 \pm 2.2$ & & 21 & $<10$ & & 74 & 0.039 \\
\hline SubPure & Calcinated & 6.1 & $9020 \pm 955$ & $101 \pm 10.1$ & $42.4 \pm 4.1$ & 24 & 37 & & & 39 & 0.041 \\
\hline BH1-100 & Grey slime & 7.8 & $1780 \pm 128$ & $27.9 \pm 2.0$ & $70.8 \pm 4.4$ & 69 & $<10$ & & $<10$ & 14 & 0.042 \\
\hline BH1-500 & Grey slime & 8.1 & $1170 \pm 26$ & $27.0 \pm 0.7$ & $72.8 \pm 1.7$ & 46 & 31 & & & 24 & 0.036 \\
\hline
\end{tabular}

* IVBA refers to in vitro bioaccessibility determined using the gastric phase of the SBRC assay. 
Table 3. Particle size analysis of selected mine-impacted materials.

\begin{tabular}{|c|c|c|c|c|c|}
\hline \multirow{2}{*}{ Sample } & \multirow{2}{*}{ Classification } & \multicolumn{4}{|c|}{ Particle Size Distribution (\%) } \\
\hline & & $1 \mu \mathrm{m}$ to $25 \mu \mathrm{m}$ & $>25 \mu \mathrm{m}$ to $<50 \mu \mathrm{m}$ & $>50 \mu \mathrm{m}$ to $<200 \mu \mathrm{m}$ & $>200 \mu \mathrm{m}$ to $<250 \mu \mathrm{m}$ \\
\hline GA1 & Tailings & 13 & 5 & 3 & 79 \\
\hline BH12 & Tailings & 85 & 15 & 0 & 0 \\
\hline \#4568 & Calcinated & 67 & 33 & 10 & 0 \\
\hline SubPure & Calcinated & 92 & 8 & 0 & 0 \\
\hline BH1-100 & Grey slime & 89 & 11 & 0 & 0 \\
\hline BH1-500 & Grey slime & 90 & 10 & 0 & 0 \\
\hline
\end{tabular}




\section{References}

[1] M. V. Ruby, A. Davis, R. Schoof, S. Eberle, and C. M. Sellstone, Estimation of Lead and Arsenic Bioavailability Using a Physiologically Based Extraction Test, Environmental Science \& Technology. 30 (1996) 422-30.

[2] S.C. Hamel, K. M. Ellickson, and P. J. Lioy, The Estimation of the Bioassiccibility of Heavy Metals in Soils Using Artificial Biofluids by Two Novel Methods: Mass-Balance and Soil Recapture, Science of the Total Environment. 243 (1999) 273-83.

[3] A. G. Oomen, A. Hack, M. Minekus, E. Zeijdner, C. Cornelis, G. Schoeters, W. Verstraete, T. Van de Wiele, J. Wragg, C. J. M. Rompelberg, Ajam Sips, and J. H. Van Wijnen, Comparison of Five in Vitro Digestion Models to Study the Bioaccessibility of Soil Contaminants, Environmental Science \& Technology. 36 (2002) 3326-34.

[4] V. Ettler, B. Kribek, V. Majer, I Knesl, and M. Mihaljevic, Differences in the Bioaccessibility of Metals Metalloids in Soils from Mining and Smelting Areas (Copperbelt, Zambia), journal of Geochemical Exploration. 113 (2012) 68-75.

[5] B. Palumbo-Roe, and B. Klinck, Bioaccessibility of Arsenic in Mine Waste-Contaminated Soils: A Case Study from an Abandoned Arsenic Mine in Sw England (Uk), J Environ Sci Health A Tox Hazard Subst Environ Eng. 42 (2007) 1251-61.

[6] L. Meunier, S. R. Walker, J. Wragg, M. B. Parsons, I. Koch, H. E. Jamieson, and K. J. Reimer, Effects of Soil Composition and Mineralogy on the Bioaccessibility of Arsenic from Tailings and Soil in Gold Mine Districts of Nova Scotia, Environmental Science \& Technology. 44 (2010) 2667-74.

[7] R. Toujaguez, F. B. Ono, V. Martins, P. P. Cabrera, A. V. Blanco, J. Bundschuh, and L. R. G. Guilherme, Arsenic Bioaccessibility in Gold Mine Tailings of Delita, Cuba, Journal of Hazardous Materials. 262 (2013) 1004-13.

[8] USEPA, Recommendations for Deafult Value for Relative Bioavailability of Arsenic in Soil, ed. by USEPA (2012). pp. OSWER 9200.1-113.

[9] R.R. Rodriguez. N. T. Basta, An In Vitro Gastrointestinal Method to Estimate Bioavailable Arsenic in

Contaminated Soils and Solid Media, Environ Sci Technol. 33 (1999) 642-649.

[10] USEPA, Microwave Assisted Acid Digest of Sediments, Sludges, Soils and Oils, ed. by US EPA (1998).

[11] G.A. Holmgren, A Rapid Citrate-dithionite extractable iron procedure, Soil Science Society of America Journal. 31 (1967). 210-211.

[12] A.J. Kropf, S. Chattopadhyay, T. Shibata, E.A. Lang, V.N. Zyryanov, B. Ravel, K. Mclvor, K.M. Kemner, K.G. Scheckel, S.R. Bare, J. Terry, S.D. Kelly, B.A. Bunker, C.U. Segre., The New Mrcat (Sector 10) Bending Magnet Beamline at the Advanced Photon Source, Synchrotron Rad. Inst. (2010).

[13] D. G. Beak, and R. T. Wilkin, Performance of a Zerovalent Iron Reactive Barrier for the Treatment of Arsenic in Groundwater: Part 2. Geochemical Modeling and Solid Phase Studies, Journal of 
Contaminant Hydrology. 106 (2009) 15-28.

[14] B. Ravel, and M. Newville, Athena, Artemis, Hephaestus: Data Analysis for X-Ray Absorption Spectroscopy Using Ifeffit, Journal of Synchrotron Radiation. 12 (2005) 537-41.

[15] W. G. Cutler, R. C. Brewer, A. El-Kadi, N. V. Hue, P. G. Niemeyer, J. Peard, and C. Ray, Bioaccessible Arsenic in Soils of Former Sugar Cane Plantations, Island of Hawaii, Sci Total Environ. 442 (2013) 177-88.

[16] A. Manceau, M. A. Marcus, and N. Tamura, Quantitative Speciation of Heavy Metals in Soils and Sediments by Synchrotron X-Ray Techniques, in Applications of Synchrotron Radiation in LowTemperature Geochemistry and Environmental Sciences, ed. by P. A. Fenter, M. L. Rivers, N. C. Sturchio and S. R. Sutton (Chantilly: Mineralogical Soc Amer, 2002), pp. 341-428.

[17] B. Ravel, Athena User's Guide. Vol. Document version 1.5 for ATHENA version 0.8.56 (2009).

[18] K. D. Bradham, K. G. Scheckel, C. M. Nelson, P. E. Seales, G. E. Lee, M. F. Hughes, B. W. Miller, A. Yeow, T. Gilmore, S. M. Serda, S. Harper, and D. J. Thomas, Relative Bioavailability and Bioaccessibility and Speciation of Arsenic in Contaminated Soils, Environmental Health Perspectives. 119 (2011) 1629-34.

[19] A. L. Juhasz, E. Smith, J. Weber, M. Rees, A. Rofe, T. Kuchel, L. Sansom, and R. Naidu, Comparison of in Vivo and in Vitro Methodologies for the Assessment of Arsenic Bioavailability in Contaminated Soils, Chemosphere. 69 (2007) 961-6.

[20] A. L. Juhasz, J. Weber, E. Smith, R. Naidu, M. Rees, A. Rofe, T. Kuchel, and L. Sansom, Assessment of Four Commonly Employed in Vitro Arsenic Bioaccessibility Assays for Predicting in Vivo Relative Arsenic Bioavailability in Contaminated Soils, Environmental Science \& Technology. 43 (2009) 9487-94.

[21] T. R. Van de Wiele, A. G. Oomen, J. Wragg, M. Cave, M. Minekus, A. Hack, C. Cornelis, C. J. Rompelberg, L. L. De Zwart, B. Klinck, J. Van Wijnen, W. Verstraete, and A. J. Sips, Comparison of Five in Vitro Digestion Models to in Vivo Experimental Results: Lead Bioaccessibility in the Human Gastrointestinal Tract, J Environ Sci Health A Tox Hazard Subst Environ Eng. 42 (2007) 1203-11.

[22] National Environmental Protection (Assessment of Site Contamination) Measure (NEPM), Guidance on Site-Specific Health Risk Assessment Methodology, ed. by NEPM (Australia: 2013).

[23] WHO, Assessing Human Health Risks of Chemicals: Derivation of Guidance Values for Health Based Exposure Limits, Environmental Health Criteria 170, International Programme on Chemical Safety (1994).

[24] A. L. Juhasz, J. Weber, and E. Smith, Predicting Arsenic Relative Bioavailability in Contaminated Soils Using Meta Analysis and Relative Bioavailability-Bioaccessibility Regression Models, Environmental Science \& Technology. 45 (2011) 10676-83.

[25] W. Brattin, J. Drexler, Y. Lowney, S. Griffin, G. Diamond, and L. Woodbury, An in Vitro Method for Estimation of Arsenic Relative Bioavailability in Soil, Journal of Toxicology and Environmental Health-Part a-Current Issues. 76 (2013) 458-78. 
[26] M. V. Ruby, R. Schoof, W. Brattin, M. Goldade, G. Post, M. Harnois, D. E. Mosby, S. W. Casteel, W. Berti, M. Carpenter, D. Edwards, D. Cragin, and W. Chappell, Advances in Evaluating the Oral Bioavailability of Inorganics in Soil for Use in Human Health Risk Assessment, Environmental Science\& Technology. 33 (1999) 3697-705.

[27] S.R. Walker, M.B. Parsons, H.E. Jamieson, A. Lanzirotti, Arsenic mineralogy of near-surface tailings

and soils: influences on arsenic mobility and bioaccessibility in the nova scota gold mining districts, The Canadian Mineralogist. 47 (2009) 533-556.

[28] C. S. Kim, C. Chi, S. R. Miller, R. A. Rosales, E. S. Sugihara, J. Akau, J. J. Rytuba, and S. M. Webb, (Micro)Spectroscopic Analyses of Particle Size Dependence on Arsenic Distribution and Speciation in Mine Wastes, Environmental Science \& Technology. 47 (2013) 8164-71.

[29] S. R. Walker, H. E. Jamieson, A. Lanzirotti, C. F. Andrade, G. E. M Hall, The speciation of arsenic in iron oxides in mine wastes from the giant gold mine, N.W.T.: Application of synchrotron micro-XRD and micro-XANES at the grain scale, The Canadian Mineralogist. 43 (2005) 1205-1224.

[30] A. L. Foster, R.P. Ashley, and J.J. Rytuba, Arsenic species in weathering mine tailings and biogenic

solids at the Lava Cap Mine Superfund Site, Nevada City, CA, Geochemical Transactions. 12 (2011)

[31] D. Paktunc, A, Foster, S. Heald, G. Laflamme, Speciation and characterization of arsenic in gold ores and cyanidation tailings using X-ray absorption spectroscopy, Geochimica Et Cosmochimica Acta 68 (2004) 969-983.

[32] D. G. Beak, N. T. Basta, K. G. Scheckel, S. J. Traina, Bioaccessibility of arsenic(V) bound to ferrihydrite using a simulated gastrointestinal system, Environmental Science \& Technology. 40 (2006)

$1364-1370$.

[33] E. Smith, A. L. Juhasz, Arsenic distribution and bioaccessibility across particle fractions in historically contaminated soils, Environ Geochem Health. 31 (2009) 85-92.

[34] L. Meunier, I. Koch, K.J. Reimer, Effect of particle size on arsenic bioaccessibility in gold mine tailings of Nova Scotia, Science of the Total Environment. 409 (2011) 2233-2243.

[35] E. Smith, K. Scheckel, B.W. Miller, J. Weber, A. L. Juhaz, Influence of in vitro assay pH and extractant composition on As bioaccessibility in contaminated soils, Science of the Total Environment.

473 (2014) 171-177.

[36] D. M. Sherman, and S. R. Randall, Surface Complexation of Arsenie(V) to Iron(lii) (Hydr)Oxides: Structural Mechanism from Ab Initio Molecular Geometries and Exafs Spectroscopy, Geochimica Et Cosmochimica Acta. 67 (2003) 4223-30.

[37] A. Krysiak, and A. Karczewska, Arsenic Extractability in Soils in the Areas of Former Arsenic Mining and Smelting, Sw Poland, Science of the Total Environment. 379 (2007) 190-200.

[38] S. Fendorf, M. J. Eick, P. Grossl, D. L. Sparks, Arsenate and chromate retention mechanisms on 
goethite. 1: Surface structure, Environ. Sci. Technol. 31 (1997) 315-320.

[39] E. Girouard, G. J. Zagury, Arsenic bioaccessibility in CCA-contaminated soils: influence of soil properties, arsenic fractionation, and particle-size fraction, Sci. Total. Environ. 407 (2009) 2576-2585.

[40] K. Ljung, O. Selinus, E. Otabbong, M. Berglund. Metal and arsenic distribution in soil particle sizes

relevant to soil ingestion by children, Appl. Geochem. 21 (2006) 1613-1624.

[41] Z-G. Cao, G. Yu, Y-S. Chen, Q-M. Cao, H. Fiedler, S-B. Deng, J. Huang, B. Wang, Particle size: A missing factor in risk assessment of human exposure to toxic chemicals in settled indoor dust, Environ.

Internat. 49 (2012) 24-30. 